Karlo Ružičić-Kessler

\title{
The Tito-Stalin Split and its Adriatic Dimension: Regional Rifts in a "Monolithic" Movement
}

This article focuses on the question of relations in the communist camp from a regional and international perspective. The case of Trieste and its surroundings, the Julian March, shows how early after the end of World War II clashes erupted between Italian and Yugoslav communists over the fate of a region disputed between Rome and Belgrade, which became the focus of international politics on a divided continent. Indeed, when analyzing the history of communist movements and their interactions in and around Trieste in the years around 1948, one can find many parallels to a wider range of questions in the context of transnational relations. Trieste was part of Yugoslavia's agenda for control over large parts of southeastern Europe; it was also a key element of its international strategy after 1945 and, therefore, a link in a chain of ambitious projects to secure regional power. The communist scenario of Trieste also shows how different parties tried to achieve their goals inside an internationalist movement that, in principle, adhered to a common strategy. Therefore, it is an example of national agendas in an internationalist context. Moreover, this special case also reflects desires of regional parties tied to their "big brothers" in national capitals, producing their own strategies and further conflicts in the "monolithic" communist world. This article will analyze how relations between communist movements on the Adriatic developed before, during and after the Tito-Stalin split, presenting a special case of early cold war policies.

\section{The Fate of Trieste after World War II and the Communist World}

In the last days of World War II, Yugoslav partisans occupied the city of Trieste and its surroundings. The United States and the United Kingdom were not willing to give up on this important city and let it become a communist outpost. Since Soviet leader Joseph Stalin was not ready to risk open conflict with the West over the fate of Trieste, he 
ordered Tito to withdraw from the city. After 40 days of Yugoslav occupation, the partisans left the city, while the Italian territories of the Julian March were divided between the Western Allies (Zone A) and Yugoslavia (Zone B), who occupied their respective zones militarily. After the Yugoslav retreat from Trieste, the distribution of forces within the communist camp in the Julian March had to be clarified. The arrangements between the Western Allies and Yugoslavia somewhat favoured the Italian Communist Party (PCI), which had had the difficult task of manoeuvring between its alliance with the Communist Party of Yugoslavia (KPJ), while also trying to accommodate national interests during the war - especially when it came to the questions relating Italy's eastern border. The party leader Palmiro Togliatti, who did not openly support a Yugoslav Trieste but was well aware that this was the result sought by the international communist movement, as well as Stalin, found the ambiguous formula of keeping Trieste's "Italianità" and proposed for Trieste a position of a "free city". First clashes between party leaders from Rome and Belgrade had erupted during the war already, while both sides tried to gain the support from Moscow, who sided with Tito. ${ }^{1}$

These events led to a new development in the northern Adriatic. On behalf of the Communist Party of Slovenia (KPS), on 30 June 1945, the KPJ's central committee accepted the creation of an autonomous communist party for Trieste and the Julian March, under the authority of the KPS. ${ }^{2}$ On 13 August 1945, the founding congress of the Communist Party of the Julian March (PCRG/KPJK) was held in Trieste. Slovene Boris Kraigher was elected secretary of the party. ${ }^{3}$ The unification of all communist forces also reflected the retreat of the PCI from the region ${ }^{4}$ as the Yugoslav communists took over the organisation, while the PCI's stance would have left it with the difficult task of rhetorically defending Trieste's "Italianità", all the while collaborating with the Yugoslavs. ${ }^{5}$ Yet in the fall of 1945, some of the sections of the Italian party in Istria refused to adhere to the new party that they considered "nationalist", which caused their forced dissolution. ${ }^{6}$

The stance taken by part of the Italian communists in the Julian March definitely had validity. Far from being a party of Italian and Yugoslav communists, the PCRG/ KPJK became an instrument of Yugoslav (Slovenian) irredentism. In a resolution from 24 September 1945, the PCRG/KPJK decided to ask the population of Trieste to support the annexation of the city by Yugoslavia. The PCI leadership sent a letter to the

1 For more details see: Ruzicic-Kessler, Togliatti, Tito, pp. 182-188.

2 Sjednica Politbiroa Centralnog Komiteta Komunističke Partije Jugoslavije, 30.6.1945, in: Izvori za Istoriju Jugoslavije, p. 74.

3 Komunistička Partija Julijske Krajine, AJ, ACKSKJ, IX-18/II-1.

4 Karlsen, Frontiera, p. 100f.

5 Ibid., p. 96.

6 Verbale dell'incontro di Pratolongo con Bussano e Mastromarino di Capodistria, 21.11.45, APCI, M, Microfilm [mf.] 094, fasc. III/g/doc. 22. 
comrades of the PCRG/KPJK, asking them to recede from their position and to "await the decisions of the [peace] conference," as had been previously accepted by both Rome and Belgrade. Moreover, the PCI declared that if the PCRG/KPJK was to publish its resolution, it would openly disapprove of this. ${ }^{7}$ Indeed, on 7 October the party in Trieste and the mass organisation UAIS supported the principle that Trieste should become part of the Federal Republic of Yugoslavia. ${ }^{8}$ The argumentation of this decision revolved around the "Marxist-Leninist" development in Yugoslavia and the "prospective of the revolution in Europe and the world" by strengthening areas "where revolutionary forces" had won the upper hand. ${ }^{9}$ Since the party in Trieste had clearly affirmed its position on the future of the city, the PCI needed to exhibit some reaction. ${ }^{10}$ In an article in the party periodical l'Unità, member of the PCI leadership Luigi Longo described the Italian party's attitude. On the one hand, Longo attacked the Italian "reaction" that had used inflammatory "anti-Slavonic" words and had thus "forced" the communists in Trieste to demand a Yugoslav annexation. On the other hand, he also disapproved of the line followed in Trieste because the workers of the city "also had to think of all Italian workers" and not just of themselves. ${ }^{11}$

Taking into account the broader picture drawn by the events of late summer and fall of 1945, it can be asserted that the pro-Yugoslav communists had taken steps to enforce their (national) vision of the future settlement of disputes in Trieste and the Julian March. The PCI, on the contrary, rather argued along internationalist and "class" lines. This all makes sense when one considers that Yugoslav organisations could count on the backing of the government in Belgrade which pursued its national interests with the support of Moscow. ${ }^{12}$ The Italian communists were still in a fragile position whereby they had to back Yugoslav claims, according to the leading figure of Moscow, but also work in a democratic, parliamentary system, where an overtly internationalist course could mean a loss of votes. Thus, as Longo depicted in his article, the optimum choice - defending Trieste's "Italianità" while simultaneously backing Yugoslavia - was an attempt to satisfy all the currents within Italy as well as within the international communist movement.

In continuation of its attempts to reach a useful agreement with their Yugoslav comrades, the PCI continued to seek dialogue with their counterparts in the Julian March and Belgrade throughout 1945 and in early $1946 .{ }^{13}$ The Fifth Congress of the PCI, held in December 1945 and January 1946, saw Togliatti positioning himself within the stance

7 Lettera della direzione del PCI alla direzione del PCRG, APCI, M, mf. 095, fasc. r/doc. 8.

8 Appunti per una discussione sul problema di Trieste, 10.1.46, APCI, M, mf. 95, fasc. r/doc. 9.

9 Ibid.

10 Karlsen, Frontiera, p. 117.

11 Longo, Luigi, Per una miglior difesa dell'italianità di Trieste, l'Unità, 30.10.1945.

12 In fact, the representatives from the Julian March complained at Politburo meetings in Belgrade about the behaviour exhibited by the Italian communists and their stance on the "free city". See: Kidrič to Kardelj, AJ, ACKSKJ, IX-13/10; Izvori za Istoriju, $115 f$.

13 Smodlaka to Tito, 12.11.1945, AJ, ACKSKJ, IX-48/I-13. 
pursued by the Party in the previous months. Considering the question of the borders, he emphasised the "Italianità" of Trieste, omitting a direct reference to border questions but asking for a solution that would foresee the involvement of Italy and Yugoslavia in the process. He also declared solidarity with Yugoslavia, showed his understanding for the "workers of Trieste" who did not trust the Italian state, but also disapproved of their desire of being integrated into Yugoslavia. ${ }^{14}$ Meanwhile, Yugoslav propaganda accused Togliatti of working for the "Italian reactionaries" and thus made the discordance within the communist movement public. ${ }^{15}$ As the question of an "internationalisation" of Trieste $^{16}$ became more relevant in international meetings, the PCRG/KPJK suggested that the communist forces refuse this solution and recognise that the inclusion of the Julian March into Yugoslavia was the only acceptable solution for the Slavonic majority of the population. Until the implementation of such an agreement, the PCRG/KPJK would hold the position that Trieste and the Julian March should be incorporated into Yugoslavia. Moreover, the Italian-Slavonic unity persisted as an instrument "against fascism and nationalism". Therefore, the party in the Julian March would only agree to propositions accepted by both the PCI and the KPJ ${ }^{17}$ Thus, the communists in the Julian March pushed for a clear pro-Yugoslav stance once again, while at the same time criticising the disputes created between the Italian and Julian parties. The PCI responded with a counter proposition. It would not "renounce the Italianità of Trieste" or raise the question of Trieste's state affiliation, as this would cause major problems within Italy and could be exploited by "reactionary forces". Moreover, the PCI supported the self-determination of all peoples and "Italian national unity" was seen as a duty of all democratic forces. ${ }^{18}$ Taking these issues into account, the PCI proposed a catalogue of measures: the unity of the Italian and Slavonic communists in the PCRG/KPJK should be granted; to achieve this, the PCRG/KPJK should refrain from disseminating pro-annexation propaganda; the Italian and Slavonic communists in the region should adhere to the fight for self-government of the city, letting the people of Trieste decide their fate themselves; the PCRG/KPJK should secure adequate representation of the two nationalities and should be organically linked to the PCI, the KPS and the KPJ to prevent divergence within the party. ${ }^{19}$ By demanding closer ties with the Italian and the Yugoslav parties, the PCI would ensure that Ljubljana and Belgrade loosen their grip on

14 More details on the speech in: AJ, ACKSKJ, IX-48/I-14; also the analysis of Karlsen, Frontiera, p. 122f.

15 See: Gibiansky, Trieste, p. 204f; AJ, ACKSKJ, IX-48/I-17; Borba, 2.2.1946 and Josip Broz Tito, Govori i članci, p. $168 f$.

16 The internationalisation had already been examined by the Allies in 1945 following the partition of the Julian March. In 1946, it became more and more obvious that this solution would become the one favoured at the peace conference. See: Rainero/Manzari, Trattato di pace.

17 Documento proposta dai delegati del PCRG, 17.1.1946, APCI, M, mf. 095, fasc. r/doc. 10.

18 Posizione della segreteria del PCI sui rapporti col PCRG, 26.1.46, APCI, M, mf. 095, fasc. r/doc 10, also: AJ, ACKSKJ, IX-48/I-15.

19 Ibid. 
the party organisation of Julian March. Boris Kraigher, secretary of the PCRG/KPJK, formulated an answer to the Italian plea quite clearly: the Party would not officially take any stance on the future of Trieste. The members of the Party would only talk about the territorial question through other institutions like the UAIS and various societies. Moreover, Kraigher declared that "it is not the duty of a party member to declare his position on the [territorial question]. It is [however] the duty of those who do not embrace the Yugoslav solution, not to declare themselves in favour of any other position." ${ }^{20}$ Thus, it was obvious that the two parties would not easily come to an agreement of what was "right" and "wrong" for the international communist movement. Yugoslav leader Tito clearly supported the representatives of the PCRG/KPJK at their meetings with the Politburo in Belgrade. He also refrained from giving in to Italian demands no matter how difficult the situation for the PCI was. Once again, this dispute demonstrated that the logic behind the struggle of the two factions was completely opposite. In fact, Kraigher was quite right when he referred to the incorporation of the PCI into a "bourgeois" system and that this made a difference. The supporters of Yugoslavia backed national ideas and expansionist aspirations of the regime in Belgrade, while the PCI argued along internationalist lines, since it had no direct power in the contested territory and thus had to search for a compromise. ${ }^{21}$

Meanwhile, Tito and Edvard Kardelj complained to the Soviet ambassador to $\mathrm{Yu}-$ goslavia, Anatolij Lavernt'ev, in mid-April 1946 about the PCI and its policy regarding the question of Trieste. The PCI was accused of taking almost the same stance as the other Italian parties, and the Italian communists were also denounced as being "social-democrats" in their views. In this case, Soviet documents show that Moscow was not satisfied with Yugoslav policy since Belgrade had made the discord within the communist movement in January public, and the Kremlin understood that the PCI could not support the Yugoslav cause without losing face before the Italian public. ${ }^{22}$ Togliatti, who was holding on to the "free city" proposition for Trieste, asked for a compromise when he meet the Soviet ambassador to Italy, Mikhail Kostylev, in May 1946. Togliatti argued along the lines of a common Italian-Yugoslav agreement, as he had done several times before, and asked the Soviets to support his proposition at the peace conference. Kostylev responded negatively, concluding that leaving Trieste out of Yugoslavia was akin to "separating the head from the body." ${ }^{23}$ Furthermore, just days after this exchange between Togliatti and Kostylev, a Yugoslav delegation headed by Tito visited Moscow.

20 Boris Kraigher alla segreteria del PCI, 6.2.46, APCI, M, mf. 095, fasc. r/doc 12.

21 See: Situazione politica a Trieste e Udine, Allegato 2, Situazione a Trieste, APCI, M, Verbali Segreteria 19441948, mf. 271, p. 24, 26.7.1946; Riassunto di Pratolongo per la direzione del PCI su una riunione con Babic e Jaksetic, 19.8.1946, APCI, M, mf. 096, fasc. t/doc. 8; Situazione a Trieste, APCI, M, Verbali Segreteria 19441948, mf. 271, p. 21, 2.12.194; Viaggio del compagno Longo, Ibid., p. 21, 11.12.1946, AJ, ACKSKJ, IX-48/I-33.

22 For more details see: Gibiansky, Trieste, pp. 205-207.

23 Aga-Rossi/Zaslavsky, Togliatti, p. 149. 
Stalin asked if, in the case of the creation of a "free territory", this would have to include the surroundings of Trieste. Tito replied that the suburbs were Slovene and, thus, only the city could be granted special status, although he still argued for a complete inclusion of the area into Yugoslavia. ${ }^{24}$ Moreover, the Yugoslav proposition foresaw the loss of territorial integrity between Italy and Trieste, a stance abandoned only in $1954 .{ }^{25}$

Thus, the Italian and the Yugoslav communists tried to generate a favourable approach in Moscow before the next round of peace talks in June 1946. Stalin's position on the question of Trieste had until then been pro-Yugoslav. Yet, Stalin had already informed Tito in May that the Western Allies were not giving in on Trieste at the peace conference. ${ }^{26}$ This was identical to Soviet foreign minister Vyacheslav Molotov's experience in Paris in June. His discussions with the Western Allies proved difficult on the question of Trieste, and he was not able to impose the Soviet line. Thus, on 23 June, Stalin telegraphed Paris that "we must not derail the [...] conference of ministers because of the issue of Trieste $[\ldots]$ If there is an agreement on other issues, $[\ldots]$ we could propose a modus vivendi analogous to Togliatti's proposal, i.e. the internationalization of the port of Trieste and a condominium of Yugoslavia and Italy [...]." ${ }^{{ }^{27}} \mathrm{~A}$ compromise was reached on 3 July 1946 with a plan to create a free territory. Finally, the partition was formalised with the signing of the Peace Treaty with Italy on 10 February 1947. Yugoslavia annexed most of the Eastern Adriatic territories formerly belonging to Italy. A small strip of land, including Trieste, Capodistria/Koper and Cittanova/Novigrad would form the so-called Free Territory of Trieste (FTT), acting as a buffer between Italy and Yugoslavia, placed under the jurisdiction of the United Nations after the installation of a governor appointed by an international body. ${ }^{28}$ Since the governor of the FTT was never appointed, the situation de facto remained a partition of the territory between an Anglo-American "Zone A", consisting of Trieste and the coastal strip leading north to Duino, and a Yugoslav "Zone B" to the east and south, including the north-western part of Istria.

\section{Trieste, the Cominform and the Rift}

The signing of the peace treaty with Italy led to a reorganisation and a reshuffling of the situation in what was supposed to become the FTT. A new party was needed for the region, one which would ensure better cooperation between the Italian and Yugoslav communists. In late 1946, representatives of the PCI met with their Slovenian comrades and agreed to enhance the PCI's position in Trieste. ${ }^{29}$ Thus a solution was sought out

24 Gibianskii, Soviet and Yugoslav Records, p. 119.

25 Taviani, Giorni di Trieste, pp. 126-128.

26 See: Valdevit, Dilemma, p. 86f; Cattaruzza, Confine, p. $301 f$.

27 Pechatnov, Allies, p. $17 f$.

28 Cialdea/Vismara, Documenti della; Varsori, Trattato di pace, pp. 156-163.

29 Situazione di Trieste, APCI, M, Verbali Segreteria 1944-1948, mf. 271, p. 24, 23.1.1947. 
involving Belgrade, whose position on the matter had in the meantime shifted towards a more pragmatic stance, also factoring in Tito's acceptance of potential Italian control over Trieste as a viable option before the signing of the Peace Treaty with Italy.

Luigi Longo led the discussions with his eastern comrades. In early April 1947, he visited Belgrade to discuss the future order of the FTT. Longo and Milovan Djilas signed an agreement that expressed a will to convene for a congress of the PCRG/KPJK as soon as possible in reaction to the results of the peace conference, to rename the party, and to form a new manifesto. ${ }^{30}$ The UAIS was to broaden its action in response to "the reactionary groups and American and English imperialist agents." ${ }^{11}$ Moreover, the PCI was to campaign for an autonomous status for the Friuli region. ${ }^{32}$

The man assigned to the task of enforcing the decisions reached in Belgrade in April was Vittorio Vidali, an Italian communist who had fought for the international cause in South America during the fascist period. ${ }^{33}$ After years of problems, especially with the pro-Yugoslav leadership in Trieste, the PCI was sending a strongman to the city, whose credentials in the international communist movement were impeccable. It soon became apparent within the PCI that Vidali and the old guard would not get along easily. Indeed, his pro-Yugoslav comrades were trying to stall and not convene the congress, waiting instead for the nomination of a governor of the FTT. ${ }^{34}$ Vidali's point of view becomes clear when one analyses a letter he sent to the leadership of the PCI. In his opinion, it was time to "leave aside insecurities and apply the recent resolution"; to understand "that Italy is not the enemy" and to "bring to an end the lack of respect for promises and pacts" while the "hostility towards the PCI" had "to end once and for all." 35

While the Italian movement to reform the PCRG/KPJK was trying to gain momentum, the position of the PCI in Italy changed dramatically. After a governmental crisis in May, the left (the Communists and the Socialists) was ousted from the government. ${ }^{36}$ The international situation had also changed considerably with the implementation of the "Marshal Plan" in June and the escalation of the East-West conflict during that same period, which would lead Moscow to promote a tighter grip on the communist parties in Western Europe. ${ }^{37}$

Finally, in late August 1947, the inaugural congress of the new Communist Party of the Free Territory of Trieste (PCTLT/KPTO/KPSTT) was held under the cover of a re-launch for the regional movement by the Italian communists. ${ }^{38}$ The party leadership

30 See: AJ, ACKSKJ, IX-46/I-56; APCI, M, Verbali Segreteria, mf. 268, p. 435, n. 41.

31 Direzione PCI al comitato circondariale del PCRG di Gorizia, Monfalcone e Gradisca, Risoluzione, 28.3.1947, APCI, M, mf. 247/248.

32 AJ, ACKSKJ, IX-46/I-56; APCI, M, Verbali Segreteria, mf. 268, p. 435, n. 41.

33 Il Lavoratore, 19.6.1947.

34 Relazione di Pratolongo sul rientro a Trieste di Vidali, 29.5.1947, APCI, M, mf. 096, fasc. t/doc 20.

35 Lettera di Vidali, Ibid.

36 Craveri, De Gasperi, pp. 267-302; Aga-Rossi/Zaslavsky, Togliatti, pp. 217-221.

37 Pons, Origins, pp. 14-16.

38 Congresso costitutivo del PCTLT, 31.8.-2.9.1947, APCI, M, mf. 098, fasc. 56/1. 
remained deeply divided after the congress however, as the Yugoslav wing continued to argue that it did not want to take orders from Rome, that it was still faithful to Belgrade, while at the same time mocking the Italians who had been "kicked out of government." 39

Indeed, the repercussions of the new political situation were felt by the PCI in connection with the creation of the Communist Information Bureau (Cominform) and its founding conference in Szklarska Poręba, Poland, in September 1947. The PCI (along with the French PCF) took a severe beating by the Soviets and suffered an even worse defeat by the Yugoslavs, who profoundly criticised the Italian communists' approach towards internal and international matters and even the entire war period. Criticism by the Soviet Union led the PCI to use even harsher words against the Marshal Plan, "American imperialism", to strongly adhere to "peace campaigns" and to demonstrate their ability to organise the masses by initiating strikes. ${ }^{40}$

Meanwhile the situation of a fractioned party leadership in Trieste was not overcome. The Belgrade agreements had created a situation in which the Italian wing of the party had become stronger than before, and the Yugoslav wing had to accept the implementation of the Italian Peace Treaty, which made it far more difficult to propagate a "Yugoslav" solution to territorial issues. Indeed, the solution to this situation was found at the next conference held by the Cominform in June 1948 with the decision to condemn Yugoslav behaviour and its overly independent approach to the questions of a Balkan Federation, the intervention in Albania, and the support for the communist movement in Greece. ${ }^{41}$ This time around, it was Togliatti who could triumph over the "failures" of Yugoslav communism and get revenge on the comrades who had so fiercely attacked the Italian communists just a few months earlier.

\section{The new communist order in the FTT}

The repercussions of the split between Stalin and Tito were strong on the Adriatic as well. The new situation led to a much-desired clarification of positions regarding Trieste and the FTT. The PCI, which remained loyal to Moscow's line, attacked Tito's "adventurism" in his foreign policy. ${ }^{42}$ In Trieste and throughout the FTT, the settling of accounts between the rivalling communist movements was fierce. Between late June and mid-July, political battles were fought over the control of the communist movement. The two major communist daily newspapers, Il Lavoratore and Primorski Dnevnik testified

39 Karlsen, Frontiera, p. 193.

40 On Szklarska Poreba: Procacci, The Cominform; Pons, Origins, pp. 16-21; Pons, Challenge, pp. 247-263; AgaRossi/Zaslavsky, Togliatti, p. 221f.

41 For further information see the volumes cited above and: Banac, With Stalin; Marković, Beograd; Zuccari, Dito sulla piaga.

42 Verbali Direzione, 8.-9.7.1948, APCI, M, mf. 199, p 12-II; Galeazzi, Togliatti, p. 102; Comunicato della direzione del PCI, l’Unità, 29.6.1948. 
to turf wars over the interpretation of the Cominform Resolution, on what to publish in this context, and on what to do with Belgrade's answer. While at first both editorial boards sided with the Soviet position, the Slovenian daily turned to the Yugoslav interpretation of events after a few days, heavily attacking the Italian comrades in the FTT. ${ }^{43}$ Moreover, the battle for the future of communism in Zones A and B had begun. In the executive committee of the PCTLT six members supported the resolution while four were against it. In the $\mathrm{CC}$, the vote was evenly split with seventeen members on each side. This situation led also to a split in the Party on the Adriatic. The resolution was accepted and the pro-Yugoslav comrades withdrew to Zone B. ${ }^{44}$ The Yugoslav Army was present there and Yugoslav administration had been implemented, so the apparatus of the Party fell in the hands of Belgrade, while any official who supported the resolution was forced to leave the Zone. ${ }^{45}$ Faced with such a scenario, the party in Trieste prepared a special congress. Before the congress, pro- and anti-resolution activists voiced their ideas at meetings held in factories, within trade unions, and among dockworkers. According to reports from pro-Cominformist circles, the workers of the city were already overwhelmingly supportive of the muscovite line. ${ }^{46}$ The special congress of the FTT was held between 21 and 23 August 1948. This was Vidali's finest hour. The party line was already clarified and he could rest assured of his victory. In his address to the congress, he repeated all of Belgrade's "mistakes" and noted that such mistakes ought to be published to develop the communist movement: "How often did the reaction think it could benefit from an open and bold system [?] The last time it was during the Moscow trials against the Trotskyists and treacherous generals. Yet the effects of this system could be felt in Stalingrad and Berlin." ${ }^{\prime 7}$ Moreover, Vidali explained that the Italian and the French communist parties had learned from their mistakes and the international criticism, while the KPJ was assuming it could repudiate the criticism of the Cominform and quit the alliance with the CPSU. Therefore, while in Zone B the KPJ tightened its grip on the communist movement, Vidali enforced his views on the comrades of Zone A, where one quarter of the members were expelled and others "re-educated". ${ }^{8}$

Therefore, the resolution of the Cominform created a clear divide between the opposing communist factions within the FTT. While the years after World War II had been characterized by the attempt both by the PCI and the KPJ to impose their respective points of view concerning the internationally disputed region, the rift inside the communist world had led to the clarification of relations on the Adriatic as well. For the Italian communists, this was definitely a relief after years of performing a balancing act

43 Cronaca avvenimenti del PC Trieste 29.6.-14.7.1948, APCI, M, mf. 099, fasc. VI.

44 Relazione sulla situazione del Partito Comunista del TLT, 30.8.1948, APCI, M, mf. 099, fasc. V.

45 Dichiarazione di Jaksetich, Semilli, Bacicchi, Burlini su fuga da zona B, 1.9.1948, APCI, M, mf. 099, fasc. V.

46 Vidali alla Direzione del PCI, 15.8.1948, APCI, M, mf. 099, fasc. VI.

47 Bozza Relazione Vidali sulla situazione del PCTLT, APCI, M, mf. 098, fasc. IIb.

48 Cronaca avvenimenti nel PC Trieste 29 giugno-14 luglio 1948, APCI, M, mf. 099, fasc. V. 
between national interests and internationalist ideals. For the Yugoslav side, the loss of the Soviet ally also meant the loss of influence in Zone A, where, before the resolution, Belgrade and Ljubljana's point of view had largely prevailed.

After June 1948, the PCI subordinated its policies toward Yugoslavia to Moscow's wishes. As there was no change in the Soviet stance before the rapprochement following Stalin's death in 1953, the relations on the Adriatic remained unremarkable. Trieste became a major hub for Soviet financial support of the PCI. Under direct supervision of Vittorio Vidali, immense funds were channeled from Trieste to the Party in Rome. ${ }^{49}$ At the same time, Vidali's regional autonomous movement needed new financial support, as funds entering the city from Yugoslavia had dried up, since cadres loyal to Belgrade had fled the city with part of the party coffers. ${ }^{50}$ The caesura of 1948 also had immediate effects on the elections in Zone A. Whereas the PCTLT gained 21.1 percent of the vote in 1949 and 18.3 percent in 1952, the PCI was able to gain majorities in similar industrial regions to the north of the FTT and in other comparable Italian regions. Vidali replied to the criticism expressed by the headquarters in Rome after the elections of 1949 in August that same year. He pointed out that it had been rather difficult to explain the position of the Cominform to large parts of the population and that this had been due to the mistakes made by the PCI. Moreover, bad economic conditions had affected the elections, whereas Vidali speculated that the "Anglo-Americans" would find a modus vivendi with "Tito's clique". In the fourteen months after the resolution, Vidali argued, Rome had done very little to explain the situation which ensued in 1948 clearly. Many "comrades had been expelled" due to their open criticism toward Yugoslavia before June 1948. These wounds, at least according to Vidali, would only heal with time. ${ }^{51}$ Nor did Vidali shy away from criticizing the relations between Rome and Trieste. The PCI did not care enough about the future and problems of the Adriatic city: "We wish to feel you closer to us. The Titoists are doing everything to discredit our Party. [...] The situation is becoming more and more aggravated. If you do not support us more often, we will make mistakes. ${ }^{2}$ What followed was a stronger commitment by the PCI toward attacks on Belgrade, most clearly manifested in articles featured in l'Unità..$^{53}$ This policy slowly changed only after Stalin's death in 1953 and the rapprochement between Moscow and Belgrade that ensued thereafter. Yet, Vidali remained a resolute opponent of any rapprochement with Tito's regime. After the meeting between Nikita Khrushchev and Tito in 1955, the leader of an autonomous communist party was not able to perform an about-turn in his views toward the Yugoslav government and the

49 Riva, Oro da Mosca.

50 Gori/Pons, Archivi di Mosca, pp. 330-333.

51 Promemoria, fto. Vidali, 31.8.1949, APCI, M, mf. 99, fasc. V.

52 Vidali a segreteria PCI Sede, 3.11.1949, APCI, M, mf. 99, fasc. V.

53 Karlsen, Frontiera, pp. 213 - a 220. 
past. A "normalization" was something he could not accept. At first, he articulated his views in an interview with Il Lavoratore.$^{54} \mathrm{He}$ continued his attacks during a meeting in Rome: "In Trieste there are some 30,000 refugees from Zone B, where denationalization processes using Nazi-methods can be witnessed daily. All of our comrades and every worker in Trieste have suffered under Tito's policies. When we talk about the Titoists, we are influenced by our experiences of the past. Therefore it is rather hard to expect from us to accept that the Titoist clique is indeed Marxist-Leninist and that Yugoslavia is a socialist country. ${ }^{55}$ The party in Rome did not accept Vidali's point of view, forcing him to withdraw his public comments and, in an effort reminiscent of Stalinist methods, he was also forced to perform an about-face and admit he had been wrong all the time. ${ }^{56}$ Thereafter, the party in Trieste performed its "normalization" and Vidali's struggle was sacrificed for the greater good of the international communist movement. The endpoint of this story was finally the dissolving of the autonomous communist party of the FTT during its sixth congress held from 28 to 30 June 1957.

\section{Conclusions}

This article has portrayed relations between the communist parties on the Adriatic after World War II, in connection with differing ideas and specific conceptions within a regional scenario. Whereas before the signing of the Italian Peace Treaty, the CP's of Italy and Yugoslavia tried to persuade Moscow of their line and the autonomous party created in Trieste sided with Yugoslavia, the national parties reached an agreement along the lines of the peace treaty, thereafter. Until June 1948, the regional party continued to promote its version of a policy toward Trieste, while it did not accept any rulings from above. The resolution of the Cominform cleared up all ambiguities in Trieste and its surroundings with a regional rift that had come with the international communist split. Thereafter, the regional party was aligned to Italy; yet, even in this scenario, the autonomous status of the party led it to form its own policies, especially after the rapprochement between Moscow and Belgrade in the 1950s, which demonstrated how important it is to analyze regional scenarios in internationalist movements.

54 La dichiarazione del comp Kruscev ed i comunisti triestini, Il Lavoratore, 30.5.1955.

55 Riunione die Segreteria, 7.6.1955, APCI, M, mf. 194, Verbali Segreteria.

56 Ibid. 


\section{Sources and literature}

\section{Archival sources}

Arhiv Jugoslavije, Arhiv Centralnog Komiteta Saveza Komunista Jugoslavije [AJ, ACKSKJ]

Arhiv Jugoslavije, Izvori za Istoriju Jugoslavije. Zapisnici sa sednica Politbiroa Centralnog Komiteta KPJ (11.jun 1945 - 7. jul 1948). Beograd: AJ, 1995.

Cialdea, Basilio/Maria Vismara (eds.), Documenti della pace italiana: Trattato di pace con l'Italia. Roma: Edizioni Politica Estera, 1947.

Fondazione Istituto Gramsci, Archivio del Partito Comunista Italiano, Fondo Mosca [APCI, M]

Gibianskii, Leonid, The Soviet Bloc and the Initial Stage of the Cold War: Archival Documents on Stalin's Meetings with Communist Leaders of Yugoslavia and Bulgaria, 1946-1948. Cold War International History Project, Bulletin 10, March 1998, pp. 112-134.

Pechatnov, Vladimir O., "The Allies are Pressing on you to Break your Will...”. Foreign Policy

Correspondence Between Stalin and Molotov And Other Politburo Members, September 1945-December 1946. Cold War International History Project, Working Paper No. 26, September 1999.

Procacci, Giuliano (ed.), The Cominform. Minutes of the Three Conferences 1947/1948/1949. Milano: Feltrinelli, 1994.

\section{Newspapers}

Borba

L'Unità

Il Lavoratore

\section{Literature}

Aga-Rossi, Elena/Viktor Zaslavsky, Togliatti e Stalin. Il PCI e la politica estera staliniana negli archivi di Mosca. Bologna: Mulino, 2007.

Banac, Ivo, With Stalin against Tito. Cominformist Splits in Yugoslav Communism. Ithaca: Cornell University Press, 1988.

Cattaruzza, Marina, L'Italia e il confine orientale. Bologna: Mulino, 2007.

Craveri, Piero, De Gasperi. Bologna: Mulino, 2006.

Galeazzi, Marco, Togliatti e Tito. Tra identità nazionale e internazionalismo. Roma: Carocci, 2005.

Gibiansky, Leonid, La questione di Trieste tra i comunisti Italiani e Jugoslavi. Elena Aga-Rossi /Gaetano Quagliariello (eds.), L'altra faccia della luna. I rapporti tra PCI, PCF e Unione Sovietica. Bologna: Mulino, 1997, pp. 173-208.

Gori, Francesca/Silvio Pons, Dagli archivi di Mosca. L'Urss, il Cominform e il PCI (1943-1951). Roma: Carocci, 1998.

Karlsen, Patrick, Frontiera rossa, Il PCI, il confine orientale e il contesto internazionale 1941-1955. Gorizia: LEG, 2010.

Marković, Predrag J., Beograd između istoka i zapada 1948-1965. Beograd: NIU, 1996. 
Pons, Silvio, A Challenge Let Drop. Soviet Foreign Policy, the Cominform and the Italian Communist Party, 1947-8. Francesca Gori/Silvio Pons (eds.), The Soviet Union and Europe in the Cold War, 1943-1953. London: Macmillan, 1996.

Pons, Silvio, Stalin, Togliatti, and the Origins of the Cold War in Europe. Journal of Cold War Studies vol. 3, No. 2, Spring 2001, pp. 3-27.

Rainero, Romain H./Giuliano Manzari (eds.), Il trattato di pace con l'Italia. Gaeta: Stabilimento grafico militare, 1998.

Riva, Valerio, Oro da Mosca. I finanziamenti sovietici al PCI dalla Rivoluzione d'ottobre al crollo dell'Urss. Con 240 documenti inediti. Milano: Mondadori 1999.

Ruzicic-Kessler, Karlo, Togliatti, Tito and the Shadow of Moscow 1944/45-1948: Post-War Territorial Disputes and the Communist World. Journal of European Integration History vol. 20 No. 2, pp. 181-202.

Taviani, Paolo Emilio, I giorni di Trieste. Diario 1953-1954. Bologna: Mulino, 1998.

Tito, Josip Broz, Govori i članci. Tom II, 8-VIII-1945-31-XII-1946. Zagreb: Naprijed, 1959.

Valdevit, Giampaolo, Il dilemma Trieste. Guerra e dopoguerra in uno scenario europeo. Gorizia: LEG, 1999.

Varsori, Antonio, Il trattato di pace italiano. Le iniziative politiche e diplomatiche dell'Italia. Antonio Varsori (ed.), La politica estera italiana nel secondo dopoguerra (1943-1957). Milano: LED, 2006, pp. 156-163.

Zuccari, Maurizio, Il dito sulla piaga. Togliatti e il Pci nella rottura fra Stalin e Tito 1944-1957. Milano: Mursia, 2008.

\section{Summary}

\section{Karlo Ružičić-Kessler}

\section{The Tito-Stalin Split and its Adriatic Dimension: Regional Rifts in a "Monolithic" Movement}

Considering the shifts and rifts inside the common communist camp during the Cold War, one always finds the question of the Tito-Stalin split of June 1948 as a landmark event for emancipation and the search for new paths to socialism, not dictated by one "monolith“. This proposal focuses on interparty relations and dialogue before, during and after the split in the perspective of one major international and transnational question: the fate of Trieste. Both the Italian and the Yugoslav CP were at the center of discussion on the future of Trieste after World War II. While Yugoslavia implemented communist rule, the Italian communists were torn between the struggle within the frame of a "Western bourgeois" democracy and the internationalist movement. The Yugoslav comrades held the upper hand for most of the time due to the support of the Soviet Union, yet the Italian communists did not give up on their "national" agenda, creating a special blend of interests in the small contested strip of land between Italy and Yugoslavia. After the Tito-Stalin split, the question was reversed. Now the Italian communists were at the forefront of the struggle against Tito and financed actions to destabilize the regime. Adding to this complex situation the autonomous communist party installed in Trieste - first dominated by Belgrade and 
after 1948 by Rome - took a surprisingly independent stance on some transnational questions before and after June 1948 - being a propaganda tool for Belgrade at first and of the Cominform thereafter. Therefore, the analysis of these interparty relations can tell us more about the question of early "emancipation" in the communist world and how it developed in the corset of a "monolithic" movement, while also revealing the repercussions of 1948 in a wider transnational party network. 